\title{
Development of Learning Devices Based on Model Eliciting Activities to Improve Students Problem Solving Ability and Mathematical Disposition
}

\author{
Novita Sari ${ }^{1 *}$, Izwita Dewi ${ }^{2}$, Edy Surya ${ }^{2}$ \\ ${ }^{1}$ Mathematics Education Study Program Postgraduate, State University of Medan, Jl. William Iskandar Psr. V \\ Medan Estate, PO box 20221, North Sumatera, Indonesia \\ ${ }^{2}$ Lecturer State University of Medan, Jl. William Iskandar Psr. V Medan Estate, PO box 20221, North Sumatera, \\ Indonesia
}

\begin{abstract}
This study aims to: 1) To analyze the improvement of problem solving abilities and mathematical disposition of students who learn to use learning devices developed with eliciting activities models 2) To analyze the validity of learning devices developed with eliciting activities models 3) To analyze the practicality of learning devices developed with the modeleliciting activities 4) students to analyze the effectiveness of learning devicesdeveloped with the modeleliciting activities. The subjects in this study were class X students of SMK Negeri 2 Medan in the academic year 2019/2020 with a total of 30 students. The results showed that: 1 . Increased students 'mathematical problem solving abilities can be seen from the calculation of N-Gain tests of students' mathematical problem solving abilities in the first try was 0.220 increased to 0.488 in the second tryout and increased to 0.546 at disseminated stage. 2. Improvement of students' mathematical disposition can be seen in each of the indicators of mathematical disposition, namely: indicator 1 (confident in using mathematics) the average score in the first try was 76.81 increased to 81.11 in the second try and disseminated stage increased to 90.28 , indicator 2 (flexible in mathematics) the average score in trial I was 74.31 increased to 80.69 in trial II and tdisseminated stage increased to 87.64 , indicator 3 (persistent and resilient in doing mathematical tasks) the average score on the first try was 76.50 increased to 80.50 in the second trial and disseminated stage increased to 83.00 , indicator 4 (have a curiosity in mathematics) on average score in trial I was 81.11 increased to 82.50 in trial II and disseminated stage increased to 83.33 , indicator 5 (reflecting on the way of thinking) the average score in trial I was 73.75 increased to 74.17 pad a trial II and disseminated stage increased to 85.21, indicator 6 (appreciate the application of mathematics) the average score in trial I was 73.33 increased to 90.63 in trial II and disseminated stage increased to 94.17 , indicator 7 (appreciating the role of mathematics / opinions about mathematics) the average score in trial I was 81.62 increased to 85.42 in trial II and the disseminated stage increased to 91.25 .
\end{abstract}

Keywords : develoment of learning devices, Dick \& Carry models, model eliciting activities (MEAs), mathematical problem solving abilitiy, mathematical disposition.

DOI: $10.7176 / \mathrm{JEP} / 11-2-15$

Publication date: January $31^{\text {st }} 2020$

\section{Introduction}

Mathematics as one of the subjects that plays a very important role in education, because it has contributed in everyday life and in the face of advances in science and technology so that mathematics needs to be taught to every student. This is in line with the statement of Hasratuddin (2015) states that mathematics is a means or way to find answers to problems faced by humans, a way of using information, using knowledge about shapes and sizes, using knowledge about counting and, most importantly, thinking within humans themselves to see and use relationships.

Given the importance of mathematics for the achievement of these learning goals, the one issue that must be prepared by the teacher before implementing learning is the learning device. Learning device play an important role, as revealed by Wahyudi (2014), namely: (1) as a learning guide; (2) as a minimum standard of teacher performance; (3) teacher performance improvement; (4) teacher performance evaluation tools. According to Latief (2009) Learning devices are a collection of learning resources arranged in such a way that students and teachers carry out learning activities that include syllabi, lesson plans, teaching materials, student worksheets, learning media, tests to measure learning outcomes and some of them. An important factor for determining the success of teaching is a clear idea of the lessons they want to organize and prepare. According Dewi and Harahap (2016) One of the most influential in the learning is appropriate teaching materials. This is in line with Kyriacou (2009) saying that careful preparation is needed for successful learning. The form of learning preparation is a learning device. Therefore, in carrying out their duties, teachers must develop and develop learning devices.

From the observation of the textbooks used at SMKN 2 Medan has weaknesses, namely: (1) textbooks are not student-centered; (2) the questions in the book still do not lead to improve students' mathematical problem solving abilities; and (3) lack of presentation of contextual problems. One mathematical ability that needs to be improved is the problem solving ability. This is because the ability to solve mathematical problems is the most important thing in learning mathematics in class, because the ability to solve problems can be useful for daily life or become new 
knowledge that can be used later in life. Ismawati (2014) suggested that problem-solving skills are very important not only for those who later will explore mathematics, but also for those who will apply it in other fields of study and everyday life. The importance of problem solving skills in students is also seen in the statement of Branca (1980) which states that (1) problem solving ability is a general goal of learning mathematics; (2) problem solving includes methods, procedures and strategies which are the core and main processes in the mathematics curriculum; (3) problem solving is a basic ability in learning mathematics. Furthermore Polya (1973) said problem solving is one aspect of higher level thinking, as a process of accepting problems and trying to solve those problems. So problem solving is a high level of intellectual activity, and students are encouraged and given the broadest opportunity to take the initiative and think systematically in dealing with a problem by applying knowledge gained previously.

Responding to problems that occur in the field that is in the process of learning mathematics at school, especially those related to the importance of mathematical problem solving abilities and mathematical disposition which ultimately results in low learning outcomes in mathematics. There needs to be a solution in the form of a learning model that can accommodate an increase in students' mathematical problem solving abilities and mathematical disposition. One of them is the model elicting activities (MEAs). Wessels (2014) said model elicting activities (MEAs) are complex, open, non-routine problems in a variety of real-world contexts that can ve approached by learners at different entry levels and then solved throught the interaction between their informal and more formall mathematical knowledge.

The results of research conducted by Garfield, delMas and Zieffler (2010) show that using the learning model eliciting activities (MEAs) helps students prepare themselves to learn statistical content that leads to conceptual understanding, problem solving skills, retention, and better knowledge transfer. This is what drives the author to conduct research with the title is Development Of Learning Devices Based On Model Eliciting Activities to Improve Stundents Problem Solving Ability and Mathematical Disposition

\section{Methods}

\section{Research Pattern}

The learning device development model that will be carried out is the Dick \& Carey development model for several reasons, namely: the Dick \& Carey model has been widely used to develop effective devices, every step of the Dick \& Carey model is feedback or revised, a systematic initial step and repeated testing shows the results obtained can be accepted and assured, the steps of the Dick \& Carey model are very concise, concise and clear and are interconnected with one another and in accordance with the applicable curriculum. The procedure for the Dick \& Carey development model can be described as follows:

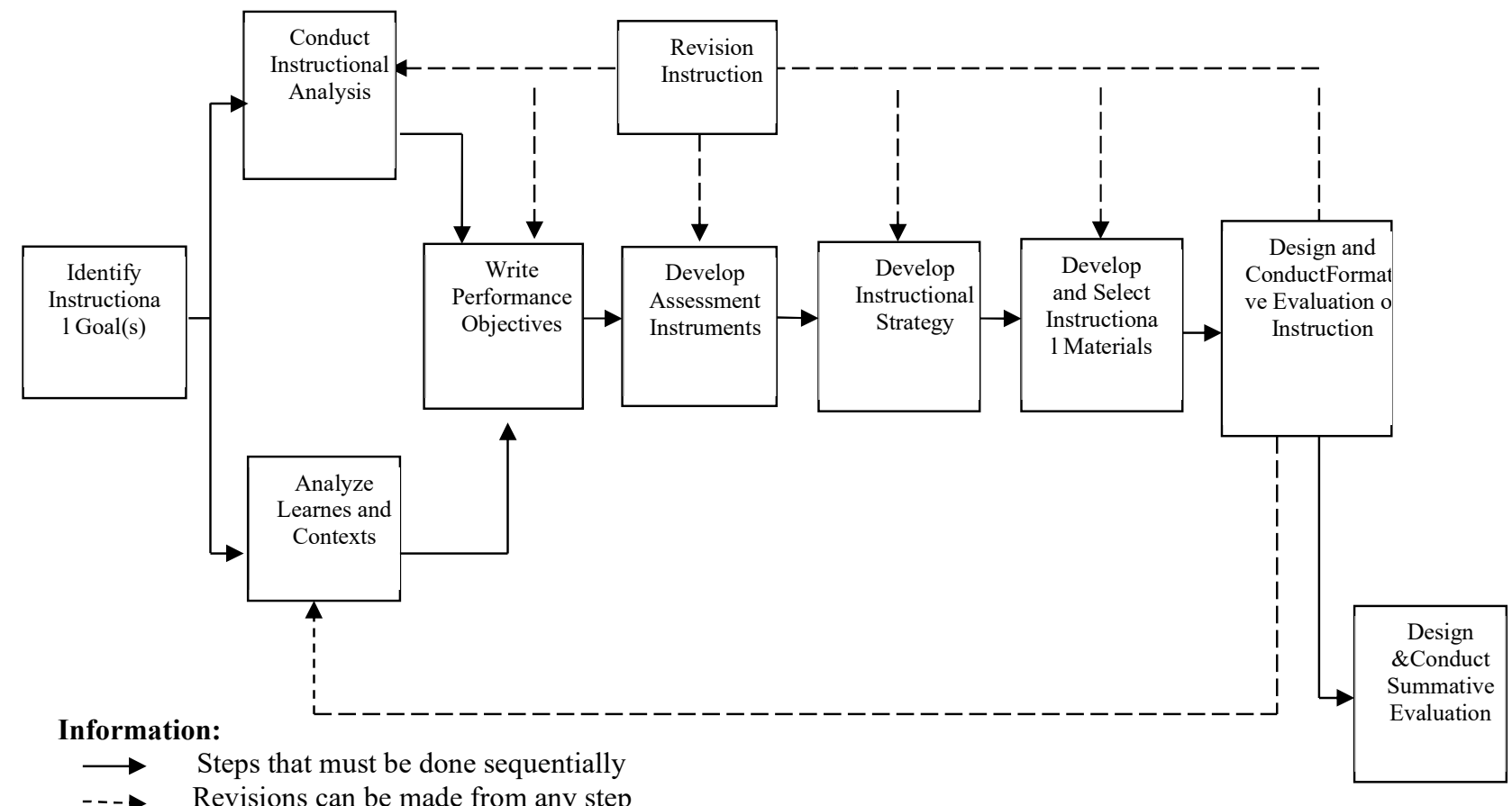

Picture 1.Development Style Dick \& Carey

(Dick \& Carey, 2009) 


\section{Participants}

The subjects in this study were class X students of SMK Negeri 2 Medan in the academic year 2019/2020 with a total of 30 students.

\section{Data Collection Technique}

The devicesused to collect data to determine the level of mathematical reasoning ability of students is the description test. Mathematical problem-solving ability test (TKPMM), is used to obtain information about students' mastery of the topic of linear programming after being given a learning devices based on eliciting model activities. The TKPMM instrument was given at the end of the learning meeting and took the form of a description test. The test is given at the end of the learning meeting and the test instrument is developed by the researcher himself

\section{Validity and Reliability}

The learning device validation sheet is used to obtain data about the quality of the learning kit based on expert judgment. Some validation sheets that are used include: (a) The validation sheet of the lesson plan, (b) The validation sheet of the Student Activity sheet, (c) the validation sheet of student books, and (d) the book validation sheet teacher.This validation sheet contains the assessed components including: format, language, illustrations, and content.

\section{Data Analysis}

The data analysis technique used in this research is descriptive analysis. The data obtained were analyzed and directed to answer the question whether the learning device with the developed model eliciting activities meets the criteria of validity and effectiveness or not. Data obtained from expert or practitioner teams are analyzed and directed to answer whether the learning devicesdeveloped have met the validity criteria. While the trial data in the field is used to answer whether the learning devices developed have met the effectiveness criteria or not.

\section{Result and Discussion}

Based on data obtained from the results of trial I, trial II and the deployment stage will be known whether the formulation of the problem raised in the previous section has been answered or not. The results of data analysis obtained from the results of trial I, trial II and the disseminated stage showed: (1) the validity of the learning devices developed with the modeleliciting activities; (2) practicality of learning devicesdeveloped with model eliciting activities; (3) the effectiveness of learning tools developed by eliciting activities models; 4) improvement of students' mathematical problem solving abilities and mathematical disposition taught by model eliciting activities.

1) The Validity of Learning Devices Developed by the Model Eliciting Activities

The validity test was conducted to see the shortcomings of the learning devices developed with the eliciting activities model that was designed with attention to problems in class X SMK Negeri 2 Medan related to basic competencies, material, sample questions, practice questions and evaluations at the end of each chapter. The team of experts (validators) involved in developing this devices consisted of five experts. The results of the validation of the five validators stated valid with an average total validity of LKPD of 4.46, teacher's books of 4.48, student books of 4.52. Then the test results of the mathematical problem solving ability test instrument and the mathematical disposition questionnaire statement items also have been in the valid category based on the trial results showing tcount $>$ ttable, the test instruments and questionnaires can be used and valid. The pretest reliability of mathematical problem solving ability is 0.663 (high category) and posttest mathematical problem solving ability is 0.674 (high category). The reliability disposition questionnaire results also showed 0.876 (very high category).

From the results of the analysis above, it can be concluded that the learning devices developed with the model eliciting activities have met the validity criteria based on expert / practitioner ratings.

\section{2) Practicality of Learning Devices Developed by Model Eliciting Activities}

Based on the results of data analysis of the results of trial I, trial II and disseminated stage obtained, the practicality of the learning devicesbased on the summary of observations of the results of the implementation of mathematics learning with models eliciting activities at each stage can be seen in table 1. below :

Table1. Summary of Observation Results of Learning Implementation at Each Trial Phase

\begin{tabular}{cc}
\hline Step & Average Percentage of Learning Execution \\
\hline Trial I & $84,76 \%$ \\
Trial II & $86,67 \%$ \\
Disseminated & $89,05 \%$ \\
\hline
\end{tabular}


Based on table 4.34 it can be seen that the average percentage of learning outcomes in trial I was $84.76 \%$, in trial II was $86.67 \%$ and in the deployment stage was $89.05 \%$. Thus it can be concluded that the implementation of learning at each stage has met the practical criteria and is in the good category $(80 \leq \mathrm{k}<90)$.

\section{3) The Effectiveness of Learning Devices Developed With Model Eliciting Activities}

Based on the results of Trial II and the disseminated stage, the learning tools developed using the model eliciting activities have met the effective categories in terms of: (1) completeness of student learning classically; (2) the achievement of learning objectives in each item has reached the specified criteria which is at least $75 \%$. The following will be presented a discussion for each indicator in measuring the effectiveness of learning devices developed with modelseliciting activities.

\section{4) Completeness of Student Learning Class}

Based on the results of the posttest analysis of Trial II and the disseminated stage, it was found that the students' mathematical problem solving abilities had met the classical completeness criteria. In addition there is an increase in the results of posttest students' mathematical problem solving abilities based on classical completeness at each stage of the trial. A summary of the results of classical learning completeness in trial I, trial II and disseminated stage can be seen in table 2. below:

\begin{tabular}{cc} 
Table 2.Summary of Classical Completeness Results at Each Stage \\
\hline Step & $\begin{array}{c}\text { Percentage of classical } \\
\text { completeness }\end{array}$ \\
\hline Trial I & $70,00 \%$ \\
Trial II & $86,67 \%$ \\
Disseminated & $93,33 \%$ \\
\hline
\end{tabular}

Table 2. above shows that the percentage of completeness classically at each stage of the trial has always increased. This is because the learning process that takes place uses learning devicesthat are developed with eliciting activities models. Learning devices and contextual problems that exist in student books and LKPD are developed in accordance with the characteristics of students so that the learning process is more meaningful and students can solve problems well. This is consistent with Ausubel's learning theory (Trianto, 2011) which states that meaningful learning is a process of linking new information or material with concepts that already exist in a person's cognitive structure. Cognitive structures are facts, concepts, and generalizations that have been learned and remembered by students. This means that meaningful learning occurs when students try to connect information or new material in their knowledge structures to solve the problems they face.

$\mathrm{n}$ addition, the completeness of student learning is also influenced by the learning model used in the learning process, namely modelthe eliciting activities that makes students interested in learning and actively involved in the learning process. This is in line with what was stated by Ritonga, Surya and Syahputra (2017) obtained the results that "MEA implementation-oriented learning devices can improve students 'mathematical problem solving abilities", which implies that MEA oriented devices can improve students' mathematical problem solving abilities.

Other research regarding the modeling of eliciting activities and students 'mathematical problem solving abilities conducted by Jumadi (2017) which states that by using a model elicting activities (MEAs) can improve students' mathematical problem solving abilities. This is also supported by the results of Dzulfikar's research (2016) which concluded that the learning model of eliciting activities and problem based learning models are effective against problem solving abilities, but the learning model of eliciting activities models is better than problem based learning. Furthermore, the results of Sahara (2018) that the quality of mathematics LKS based on the model eliciting activities (MEAs) developed were classified as very valid and very practical (for small groups and large groups).

Based on the results of the previous research and research support above, it appears that the learning tools developed with the eliciting activities model can help students achieve mastery learning classically. Thus it can be concluded that the use of learning devices developed with the eliciting activities model has met the effective criteria based on classical learning completeness criteria.

\section{5) Achievement of Learning Objectives}

Achievement of learning objectives by using learning models based on eliciting activities is because learning is carried out using contextual material and problems that are close to life so that the material and contextual problems can be reached by students' imagination which makes it easier for students to look for various possible solutions by doing modeling in the form mathematical symbols or equations and solve the contextual problem with the model found. This is relevant to Bruner's theory, because at the beginning of learning students do activities Summary of the average percentage of achievement of learning objectives in each trial can be seen in table 3 . below 
Table 3. Summary of the Average Percentage of Achievement of Student Learning Objectives in each Trial Phase

\begin{tabular}{|c|c|c|c|c|}
\hline \multirow[t]{2}{*}{ Step } & \multicolumn{4}{|c|}{ Percentage of Average Achievement of Learning Objectives } \\
\hline & No & A & B & $\mathbf{C}$ \\
\hline \multirow[t]{3}{*}{ Trial II } & 1 & $85 \%$ & $76,67 \%$ & $71,67 \%$ \\
\hline & 2 & $78,33 \%$ & $70 \%$ & $66,67 \%$ \\
\hline & 3 & $76,67 \%$ & $58,33 \%$ & $45 \%$ \\
\hline \multirow[t]{3}{*}{ Trial II } & 1 & $90,83 \%$ & $90 \%$ & $90 \%$ \\
\hline & 2 & $77,5 \%$ & $76,62 \%$ & $76,67 \%$ \\
\hline & 3 & $77,5 \%$ & $76,67 \%$ & $75 \%$ \\
\hline \multirow[t]{3}{*}{ Disseminated } & 1 & $90 \%$ & $94,17 \%$ & $93,33 \%$ \\
\hline & 2 & $77,5 \%$ & $75,83 \%$ & $76,67 \%$ \\
\hline & 3 & $88,33 \%$ & $83,33 \%$ & $81,67 \%$ \\
\hline
\end{tabular}

Table 3. above shows that the percentage of achievement of learning objectives at each stage of the trial. If the results of the analysis are referred to the criteria set out in chapter III, it can be concluded that the achievement of the learning objectives meets the criteria in the pilot phase II and disseminated stage. This means that the learning devices developed using the model eliciting activities have met the effective criteria.

6) Improving Students' Mathematical Problem Solving Abilities Using Learning devices With Model Eliciting Activities

Descriptions of improving students' mathematical problem solving abilities using learning devices with model eliciting activities at each of these stages are shown in table 4.

Table 4.Description of Results Mathematical Problem Solving Ability

\begin{tabular}{cccc}
\hline Information & $\begin{array}{c}\text { Posttest } \\
\text { Trial I }\end{array}$ & $\begin{array}{c}\text { Posttest } \\
\text { Trial II }\end{array}$ & $\begin{array}{c}\text { Posttest } \\
\text { Spread Phase }\end{array}$ \\
\hline Highest Value & 80,00 & 93,30 & 96,67 \\
Lowest Value & 56,67 & 60,00 & 66,67 \\
Average & 72,11 & 81,44 & 85,00 \\
\hline
\end{tabular}

Based on table 4. regarding the results of the analysis of the improvement of students' mathematical problem solving abilities in the first try, the second try and the deployment stage showed that the average posttest results in the first try was 72.11 increased to 81.44 in the second try and at the deisseminated stage increased again to 85.00.

In addition, the improvement of students 'mathematical problem solving abilities can also be seen based on the N-Gain calculation of the results of students' mathematical problem solving abilities in the first try, the second try and the deployment stage shown in table 5. below.

Table 5.Summary of N-Gain Results Mematical Problem Solving Ability

$\begin{array}{lcc}\text { Trial I } & \text { Trial II } & \text { Disseminated } \\ 0,220 & 0,488 & 0,546\end{array}$

Based on table 5.it can be seen that in the first trial, the second trial and the disseminated increased from 0.220 to 0.488 and the re-deployment stage increased to 0.546 . This shows that the mathematical problem solving ability of students using learning devices developed with the model eliciting activities have increased from trial I, trial II and the disseminated stage.

Based on the results of previous research and research support above shows tha t learning with eliciting activities model is significantly better in improving students' mathematical problem solving abilities. So it can be concluded that the learning devices developed by eliciting activities model have a positive impact on improving mathematical problem solving ability.

7) Achievement of Students' Mathematical Disposition Taught Using Learning devices Developed by Model Eliciting Activities

Based on the analysis of students 'mathematical disposition attitude questionnaire data in the first try, the second try and the deployment stage showed that the students' mathematical disposition increased (better). The increase in mathematical disposition is seen from the average results of the mathematical disposition questionnaire filled in by students. Increased mathematical disposition is also seen in each indicator of mathematical disposition, can be seen in table 6 . below : 
Table 6.Percentage of Mathematical Disposition Score of Students in Trial I, Trial II and Disseminated Stage

\begin{tabular}{clrcc}
\hline No & \multicolumn{1}{c}{ Indikator } & Trial I & Trial II & Disseminated \\
1 & Confident in using mathematics & 76,81 & 81,11 & 90,28 \\
2 & Flexible in mathematics & 74,31 & 80,69 & 87,64 \\
3 & Persistent and tenacious in doing math tasks & 76,50 & 80,50 & 83,00 \\
4 & Having curiosity in mathematics & 81,11 & 82,50 & 83,33 \\
5 & Reflecting on ways of thinking & 73,75 & 74,17 & 85,21 \\
6 Appreciate mathematics application & 73,33 & 90,63 & 94,17 \\
7 & Appreciate the role of mathematics / opinion؛ & 81,62 & 85,42 & 91,25 \\
about mathematics & 76,79 & 82,15 & 87,84 \\
\hline
\end{tabular}

Based on Table 5.it can be seen that in trial I, trial II and disseminated increased from $76.79 \%$ to $82.15 \%$ and $87.84 \%$. This shows that the mathematical disposition of students using learning tools developed with the eliciting activities model has increased from trial I, trial II and disseminated stage.

The increase in mathematical disposition obtained from the results of the trial is in line with research conducted by Afifah research (2014), it is concluded that the level of mathematical disposition of students in the experimental group whose learning uses the learning approach model eliciting activities (MEAs) is higher than the level of mathematical disposition of students in the control group whose learning uses conventional learning approaches. In line with research conducted by Yulianti and Dahniar (2013) that the level of mathematical disposition of students with learning model eliciting activities is better than the level of mathematical disposition of students with expository learning models. Further research conducted by Mahmudi (2010) on mathematical disposition, shows the results that by comparing the average mathematical problem solving ability and mathematical disposition of students between the school categories studied, it can be seen that students who have a higher mathematical disposition tend to have mathematical problem solving abilities higher than students with lower mathematical disposition. This is seen from the average percentage of mathematical disposition of students who are in the high category of $76.78 \%, 83.44 \%$ and $86.61 \%$.

\section{Conclusion}

1. Learning devices developed by modeleliciting activities have met the valid criteria based on the results of the validity by the validator team with an average total validity of LKPD of 4.46, teacher's books of 4.48, student books of 4.52 .

2. Learning devices developed with model eliciting activities meet practical criteria in terms of:

a.) Expert / practitioner assessment which states that learning tools can be used with little revision and without revision;

b.) The results of interviews with teachers and students get information that learning devicescan be used easily.

c.) The results of observations of the implementation of learning devices in class in the first trial amounted to $84.76 \%$, in the second trial amounted to $86.67 \%$ and disseminated stage $89.05 \%$. and included in both categories.

3. In the first trial, the learning tool was not effective because it did not meet the effectiveness criteria, namely the achievement of classical learning completeness and not all the items had reached the learning objectives achievement criteria. modeleliciting activities has met the effective criteria, in terms of:

a.) Completeness of student learning has been achieved in classical trials II namely $86.67 \%$ and $93.33 \%$ disseminated stage;

b.) Achievement of learning objectives has been achieved for each item in the trial II and the disseminated stage.

4. The ability to solve mathematical problems and mathematical disposition of students using learning tools developed with modelseliciting activities increases, in terms of:

a.) Improvement of students 'mathematical problem solving abilities can be seen from the calculation of $\mathrm{N}$ Gain tests of students' mathematical problem solving abilities in the first try is 0.220 increased to 0.488 in the second tryout and increased to 0.546 at the deployment stage.

b.) Improvement of students' mathematical disposition can be seen in each of the indicators of mathematical disposition, namely: indicator 1 (confident in using mathematics) the average score in the first try was 76.81 increased to 81.11 in the second tryout and the distribution phase increased to 90.28 , indicator 2 (flexible in mathematics) the average score in trial I was 74.31 increased to 80.69 in trial II and disseminated stage increased to 87.64 , indicator 3 (persistent and resilient in doing mathematical tasks) the average score on the first try was 76.50 increased to 80.50 in the second trial and the stage of the spread increased to 83.00, indicator 4 (have a curiosity in mathematics) average the average score in trial I was 81.11 increased to 82.50 in trial II and disseminated stage increased to 83.33, indicator 5 (reflecting on ways of thinking) the 
average score in trial I was 73.75 increased to 74.17 pa in trial II and disseminated stage increased to 85.21 , indicator 6 (appreciating mathematical applications) the average score in trial I was 73.33 increased to 90.63 in trial II and the disseminated stage increased to 94.17, indicator 7 (appreciating the role of mathematics / opinions about mathematics) the average score in the first trial was 81.62 increased to 85.42 in the second trial and the disseminated stage to 91.25 .

\section{References}

Afifah.2018.The Effect of Application of Model Learning Approach-Eliciting Activities (Meas) Structured Didactic Anticipation on the Mathematical Representation and Disposition Capabilities of Middle School Students. Thesis: Sunan Ampel State Islamic University Surabaya.

Branca, N.A. (1980). Problem Solving as Goal, Process and Basic Skills. in S Krulik and R.E. Reys (Eds). Problem Solving in School Mathematics. Washington DC: NCTM

Dewi. I, M. S. Harahap. 2016. The Development of Geometri Teaching Materials Based on Constructivism to Improve the Students' Mathematic Reasoning Ability through Cooperative Learing Jigsaw at the Class VIII of SMP Negeri 3 Padangsidimpuan. Journal of Education and Practice .Vol.7, No.29

Dick, W.; Carey, L.\& Carey, J. O. 2009.The Systematic Design of Instruction, Sixth Edition.Boston.

Dzulfikar, A.2016. "The Effectiveness of Problem Based Learning and Model Eliciting Activities for the Problem Solving Ability”, Jornal of Mathematics Education, Vol.1, No.1.

Garfield, delMas \& Zieffler. 2010. Developing Tertiary Level Students' Statistical Thinking Through the Use of Model Eliciting Activities. ICOTS8 (2010) Invited Paper.

Hasratuddin. 2018. Mengapa Harus Belajar Matematika?. Medan: Penerbit Perdana Publishing.

Ismawati, D.Y. 2014. Perbedaan kemampuan pemecahan masalah matematis siswa menggunakan pendekatan diskursif metode two stay two stray dengan pembelajaran konvensional. (Skripsi). Sekolah Sarjana. Universitas Pendidikan Indonesia, Bandung.

Jumadi.2017.Application of Model Eliciting Activities (Meas) Approach in Improving the Problem Solving Ability of Class XII Students of SMA N 2 Yogyakarta. .Jurnal Matematika dan Pendidikan Matematika. Vol. 8, No. 2.

Kyriacou, C. 2009. Effective teaching in school: Theori and practice. Theory edition. United Kingdom: Nelson Thomas.

Latief, M. A. 2009. Penelitian Pengembangan. Malang: Universitas Negeri Malang

Mahmudi, A. 2010. Tinjauan Asosiasi antara Kemampuan Pemecahan Masalah Matematis dan Disposisi Matematis. Makalah Disajikan Pada Seminar Nasional Pendidikan Matematika FMIPA Universitas Negeri Yogyakarta.

Polya, G. 1973. How to Solve It. New Jersey: Princeton University Press.

Ritonga. M. E., E. Surya \& E. Syahputra. 2017. Development of Learning Devices Oriented Model Eliciting Activities to Improve Mathematical Problem Solving Ability Junior High School Students. International Journal of Sciences: Basic and Applied Research (IJSBAR) Volume 33, No 3.

Sahara, M. 2018. Pengembangan Lembar Kerja Siswa Berbasis Model-Eliciting Activities untuk Memfasilitasi Kemampuan Komunikasi Matematis Siswa Sekolah Menengah Pertama. Juring (Journal for Research in Mathematics Learning) p-ISSN: 2621-7430 |e-ISSN: 2621-7422 Vol. 1, No. 1.

Trianto. 2011. Model PembelajaranTerpadu. Jakarta: Bumi Aksara.

Wahyudi, 2014, Teacher Professional Competency Standards, Jurnal Pendidikan Sosiologi dan Humaniora. Vol 1 (2).

Wessels, H. 2014. "Levels of Mathematical Creativity in Model Eliciting Activities".Journal of Mathematical Modelling and Application, vol 1(9).

Yulianti, Dahniar E. 2013."The Effectiveness of Model Eliciting Activities on Mathematical Reasoning and Disposition Ability of Class VIII Students in Circle Material”. Unnes Journal of Mathematics Education. Vol.1 No.1. 